\title{
FULLERÉN IZOMEREK STRUKTURÁLIS JELLEMZÉSE GLOBÁLIS TOPOLÓGIAI GRÁF-INVARIÁNSOKKAL
}

\section{STUCTURAL CHARACTERIZATION OF FULLERENE ISOMERS USING GLOBAL TOPOLOGICAL GRAPH INVARIANTS}

\author{
Réti Tamás ${ }^{1}$, Felde Imre ${ }^{2}$ \\ ${ }^{1}$ Óbudai Egyetem, Bánki Donát Gépész és Biztonságtechnikai Mérnöki Kar, \\ Anyagtudományi és Gyártástechnológiai Intézet 1086 Budapest, Népszínház utca 8. \\ Telefon / Fax:+36-1-666-5386, levelezésicim,reti.tamas@bgk.uni-obuda.hu \\ ${ }^{2}$ Óbudai Egyetem, Neumann János Informatikai Kar, Biomatika Intézet, 1034 \\ Budapest, Bécsi út 96/B. Telefon/ Fax:+36-1-666-5528, levelezési cím, \\ felde.imre@nik.uni-obuda.hu
}

\begin{abstract}
In structural chemistry, fullerene-like molecules are considered as polyhedra or planar polyhedral graphs having only pentagonal and hexagonal faces. To characterize the topological structure of fullerene molecules, a novel approach is presented. The method proposed is based on the following concept: As a first step we consider the dual of the traditional fullerene graph, and as a second step, from the adjacency matrix of the corresponding dual graph, global topological invariants denoted by $\mathrm{F}(\mathrm{Q})$ are constructed. Performing comparative tests on the sets of dual graphs of $\mathrm{C}_{40}$ fullerenes, it is verified that the topological index $F(4)$ defined on the set of corresponding dual graphs can be successfully used for the quantitative structural characterization of isomers.

Keywords: fullerenes, isomers, graphs, topological descriptors

\section{Összefoglalás}

A szerkezeti kémiában, a fullerén típusú molekulákat általában poliédereknek illetve síkbeli gráfoknak szokás tekinteni, amelyek 5- és 6-oldalú sokszögeket tartalmaznak. A fullerén molekulák topológiai szerkezetének jellemzésére egy új típusú módszert ismertetünk. A javasolt módszer a következő koncepción alapul: Első lépésben a hagyományos fullerén-gráf duális gráfját generáljuk, majd a második lépésben a duális gráf szomszédossági mátrixából kiindulva, az $\mathrm{F}(\mathrm{Q})$ globális invariánsokat származtatjuk. $\mathrm{A} \mathrm{C}_{40}$ fullerén izomerek duális gráfjainak halmazán végzett összehasonlító vizsgálatok igazolták, hogy az $\mathrm{F}(4)$ topológiai index eredményesen alkalmazható az izomerek kvantitatív szerkezeti jellemzésére.
\end{abstract}

Kulcsszavak: fullerének, izomerek, gráfok, topológiai jellemzök. 


\section{Bevezetés}

A fullerének karbon-bázisú óriás molekulák, topológiai szerkezetük síkbeli gráfokkal vagy poliéderekkel modellezhető [1]. Az elmúlt évtized folyamán a témakörben folytatott kutatást alapvetően két törekvés motiválta: i) egyrészt a fullerén izomerek osztályozására alkalmas hatékonyabb eljárások kidolgozása, ii) másrészt stabilitásuk predikciójára hivatott új, megbízhatóbb módszerek kifejlesztése [2-6].

A következőkben fullerének szerkezeti jellemzésére egy módszert ismertetünk, amely lehetőséget nyújt a fullerén-gráfok strukturális jellemzésre alkalmas új típusú, ún. globális topológiai invariánsok származtatására. Ez utóbbiak definiáláshoz egy adott fullerén-izomer duális gráfja szolgál kiindulásul, amely kizárólag 5- és 6fokú csúcsokat tartalmaz. Jelölje $\mathrm{C}_{\mathrm{k}}$ a $\mathrm{k}$ csúcsszámú fullerén-izomer gráfját. Mint ismeretes a $\mathrm{C}_{\mathrm{k}}$ fullerén $\mathrm{k} \geq 22$ esetében létezik, ahol $\mathrm{k}$ páros szám. $\mathrm{A} \mathrm{C}_{\mathrm{k}}$ fullerén gráfja $\mathrm{F}_{5}=12$ számú ötszöget, és $\mathrm{F}_{6}=(\mathrm{k} / 2)-10$ számú hatszöget tartalmaz. Azonos k csúcsszámú fullerénnek több, szerkezetileg különböző izomerje létezhet.

\section{Globális topológiai gráf- invariánsok származtatása}

Jelölje $\mathrm{C}_{\mathrm{k}}^{\text {dual }}$ a megfelelő duális gráfot, és $A=A\left(C_{k}^{\text {dual }}\right)$ pedig ennek szomszédossági mátrixát. Adott fullerén-izomer szerkezeti jellemzésére hivatott $F(Q)$ topológiai invariánsokat a $\quad \mathrm{C}_{\mathrm{k}}^{\text {dual }}$ duális gráf szomszédossági mátrixa $\mathrm{A}^{\mathrm{q}}$ hatványainak felhasználásával az alábbi képlettel definiáltuk:
$F(Q)=\frac{1}{n\left(C_{k}^{\text {dual }}\right)} \sum_{\mathrm{q}=1}^{\mathrm{Q}} j^{\mathrm{T}} \mathrm{A}^{\mathrm{q}} \mathrm{j}=\frac{1}{\mathrm{n}\left(\mathrm{C}_{\mathrm{k}}^{\text {dual }}\right)} \sum_{\mathrm{q}=1}^{\mathrm{Q}} \mathrm{W}_{\mathrm{q}}$

A fenti formulában $n=n\left(C_{k}^{\text {dual }}\right) \quad a$ duális gráf csúcsszáma, $\mathrm{j}$ az n-komponensü egységvektor, míg $\mathrm{W}_{\mathrm{q}}$ mennyiségek a gráfelméletbe „walk numbers” néven ismert topológiai invariánsok [7].

Amennyiben Q nem nagyobb 4-nél, az $\mathrm{F}(\mathrm{Q})$ topológiai invariáns számítása nem igényli a duális gráf $\mathrm{A}$ szomszédossági mátrixának, illetve $\quad \mathrm{A}^{\mathrm{q}} \quad(\mathrm{q}=1,2,3,4)$ hatványainak előzetes meghatározását. Igazolható ugyanis, hogy a $\mathrm{C}_{\mathrm{k}}^{\text {dual }}$ duális gráfokra vonatkozóan a $\mathrm{W}_{\mathrm{q}}=\mathrm{j}^{\mathrm{T}} \mathrm{A}^{\mathrm{q}} \mathrm{j}$ mennyiségek ( $k=1,2,3$ és 4 esetében) az alábbi formulákkal számíthatók:

$\mathrm{W}_{1}\left(\mathrm{C}_{\mathrm{k}}^{\text {dual }}\right)=\mathrm{j}^{\mathrm{T}} \mathrm{A}^{0} \mathrm{j}=\mathrm{n}\left(\mathrm{C}_{\mathrm{k}}^{\text {dual }}\right)=(\mathrm{k}+4) / 2$

$\mathrm{W}_{2}\left(\mathrm{C}_{\mathrm{k}}^{\text {dual }}\right)=\mathrm{j}^{\mathrm{T}} \mathrm{Aj}=2 \mathrm{~m}\left(\mathrm{C}_{\mathrm{k}}^{\text {dual }}\right)=3 \mathrm{k}$

$\mathrm{W}_{3}\left(\mathrm{C}_{\mathrm{k}}^{\text {dual }}\right)=\mathrm{j}^{\mathrm{T}} \mathrm{A}^{2} \mathrm{j}=\mathrm{M}_{1}\left(\mathrm{C}_{\mathrm{k}}^{\text {dual }}\right)=18 \mathrm{k}-60$

$\mathrm{W}_{4}\left(\mathrm{C}_{\mathrm{k}}^{\text {dual }}\right)=\mathrm{j}^{\mathrm{T}} \mathrm{A}^{3} \mathrm{j}=2 \mathrm{M}_{2}\left(\mathrm{C}_{\mathrm{k}}^{\text {dual }}\right)=$

$2(54 k+\mathrm{Np}-360)$

$\mathrm{Az} n$ és $m$ pozitív egész számok, amelyek a duális gráf csúcs- illetve élszámát jelölik, az $\mathrm{M}_{1}$ és $\mathrm{M}_{2}$ mennyiségek pedig azonosak az elsô és második Zágráb index néven ismert globális topológiai mennyiségekkel [8-11].

$\mathrm{Az} \mathrm{Np}$ az eredeti $\mathrm{C}_{\mathrm{k}}$ fullerén gráf ún. pentagon indexe. Ez egy nem-negatív egész szám, azonos az egymással szomszédos ötszöglapok közös oldalszámával, és mint ismeretes, számértéke a $(0 \leq \mathrm{Np} \leq 20)$ intervallumba esik [1]. A fenti képleteket felhasználva, a $\mathrm{C}_{\mathrm{k}}^{\text {dual }}$ duális gráf $\mathrm{F}(4)$ 
globális topológiai indexének számítása az alábbi

$$
\begin{aligned}
& \mathrm{F}(4)=\frac{1}{\mathrm{n}\left(\mathrm{C}_{\mathrm{k}}^{\text {dual }}\right)} \sum_{\mathrm{q}=1}^{4} \mathrm{~W}_{\mathrm{q}}\left(\mathrm{C}_{\mathrm{k}}^{\text {dual }}\right)= \\
& \left.1+\frac{2}{(\mathrm{k}+4)}\{129 \mathrm{k}+2 \mathrm{~Np}-780)\right\}
\end{aligned}
$$

formulára egyszerüsödik.

\section{Alkalmazási példa: $\mathrm{C}_{40}$ fullerén izomerek topológiai jellemzése}

A fenti meggondolások alapján konstruált $\mathrm{F}(4)$ globális topológiai deszkriptor gyakorlati alkalmazásának demonstrálására a $\mathrm{C}_{40}$ fullerén-izomerekre vonatkozóan végeztünk vizsgálatokat. A $\mathrm{C}_{40}$ fulleréneknek éppen 40 darab izomerje létezik, ezek Np pentagon indexe a (10-20) intervallumba esik [4]. Meghatároztuk az egyes izomerek stabilitására jellemző En $(\mathrm{eV})$ energetikai paramétereket is, és elemeztük ez utóbbi és a $F(4)$ topológiai index közötti kapcsolatot. Az En energetikai paraméter számítása a Density Functional Tight-Binding (DFTB) modell felhasználásával történt [12]. Ismeretes, hogy egy fullerén izomer annál stabilabbnak tekinthető, minél kisebb En értéke. Az En energetikai paraméter és az $\mathrm{F}(4)$ index közötti összefüggést az alábbi ábra diagramja szemlélteti.

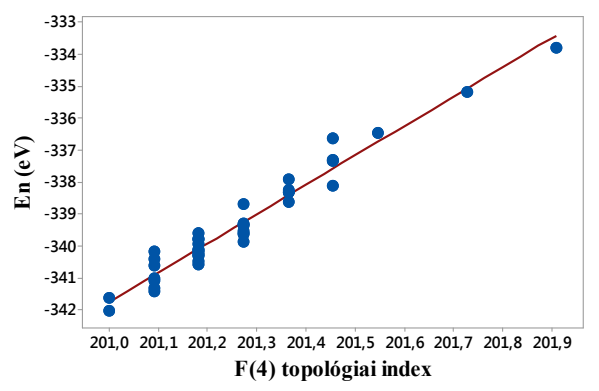

A diagramból kitünik, hogy a két mennyiség között egyértelmü lineáris jellegü összefüggés mutatkozik, ezt támasztja alá az adatpárok illeszkedésének szorosságát számszerủen is minősítő determinációs együttható $\quad\left(\mathrm{R}^{2}=0.954\right)$ kimagasló értéke.

A kapcsolat lineáris jellege annak tulajdonítható, hogy az F(4) topológiai invariáns az $\mathrm{Np}$ pentagon index lineáris függvénye.

Ebből adódó felismerés, hogy az F(4) index alapján megbízható módon következtethetünk az izomerek stabilitási sorrendjére: következésképpen azok az izomerek a leginkább stabilisak, amelyekre nézve kis értékű $F(4)$ index adódik. Az $\mathrm{F}(4)$ index minimális értéke a C40:38 és C40:39 izomerekhez tartozik, a szakirodalom szerint a 40 izomer közül éppen ezek tekinthetők a leginkább stabilnak $[2,3,4]$. Az F(4) index maximális értékét a C40:1 izomerre kapjuk, ez a legkevésbé stabil az energetikai számítások szerint.

\section{Szakirodalmi hivatkozások}

[1] P. W. Fowler and D. E. Manolopoulos: $A n$ Atlas of Fullerenes, Calendron Press, Oxford, 1995.

[2] E.E.B. Campbell, P.W. Fowler, D. Mitchell and F. Zerbetto: Increasing cost of pentagon adjacency for larger fullerenes, Chem. Phys. Lett., 250, 1996, 544-548.

[3] E. Albertazzi, C. Domene, P.W. Fowler, T. Heine, G. Seifert, C. Van Alsenoy, F. Zerbetto: Pentagon adjacency as a determinant of fullerene stability, Phys. Chem. Chem. Phys. 1, 1999, 2913-2918.

[4] P. W. Fowler: Resistance Distances in Fullerene Graphs, Croat. Chem. Acta, 75, 2002, 401-408.

[5] T. Réti, I. László, A. Graovac: Local combinatorial characterization of fullerenes, in: F. Cataldo, A. Graovac, O. Ori, (Eds.) The Mathematics and Topology of Fullerenes, Spinger Dordrecht, 2011, 61-83.

[6] T. Došlić, T. Réti, D. Vukičević: On the Vertex Degree Indices of Connected Graphs, Chem. Phys. Lett. 512, 2011, 283-286. 
[7] N. Biggs: Algebraic Graph Theory, Cambridge University Press, 1974.

[8] I. Gutman, N. Trinajstić: Graph theory and molecular orbitals. Total $\pi$-electron energy of alternant hydrocarbons, Chem. Phys. Lett. 17, 1972, 535-538.

[9] S. Nikolić, G. Kovačević, A. Miličević, N. Trinajstić: The Zagreb Indices 30 Years After, Croat. Chem. Acta, 76, 2003, 113-124.

[10] I. Gutman: Degree-Based Topological Indices, Croat. Chem. Acta, 86, 2013, 351361.

[11] B. Zhou: Zagreb Indices, MATCH Commun. Math. Comput. Chem. 52, 2004, 113-118.
[12] D. Porezag et al.: Construction of tightbinding-like potentials on the basis of density-functional theory: Application to carbon, Phys. Rev. B51, (1995) 1294712957.

\section{Köszönetnyilvánítás}

A tanulmány a TÉT_12_MX-1-2013-0001 és az "International $\overline{\mathrm{S}}$ and $\mathrm{T}$ Cooperation Program of China, Granted No. 2014DFG72020“ projektek támogatásával valósult meg. 